\title{
Soil properties improvement and use of adaptive plants for land rehabilitation of post tin mining closure in Bangka Island, Indonesia
}

\author{
PRATIWI $^{1, \boldsymbol{v}}$, BUDI HADI NARENDRA ${ }^{1}$, BUDI MULYANTO $^{2}$ \\ ${ }^{1}$ Forest Research and Development Center, Ministry of Environment and Forestry. Jl. Gunung Batu no. 5 Bogor 16118, West Java, Indonesia. \\ Tel./fax.: +62-251-8633234, `email: pratiwi.lala@yahoo.com \\ ${ }^{2}$ Department of Soil Science and Land Resources, Faculty of Agriculture, Institut Pertanian Bogor. Jl. Meranti, Kampus IPB Dramaga, Bogor 16680, \\ West Java, Indonesia
}

Manuscript received: 26 November 2019. Revision accepted: 13 January 2020.

\begin{abstract}
Pratiwi, Narendra BH, Mulyanto B. 2020. Soil properties improvement and use of adaptive plants for land rehabilitation of post tin mining closure in Bangka Island, Indonesia. Biodiversitas 21: 505-511. Indonesia is still facing several environmental problems due to improper mining activities, such as tin mining activities in Bangka island. The area of post tin mining closure in this island has left tailing area over unstructured overburden. This condition causes infertile land, which is indicated by low physical, chemical, and biological soil properties for supporting plant growth. Therefore, amelioration material is needed to increase soil fertility in rehabilitating this area. The purposes of the study are to improve soil properties and the use of adaptive plants for land rehabilitation of post tin mining closure. The observation was carried out on plots with ameliorant materials treatment, and no treatment as a control plot. Adaptive plants used are trembesi (Samanea saman), sengon buto (Enterolobium cyclocarpum), and ampupu (Eucalyptus urophylla); while ameliorant materials were mixture of overburden materials, NPK fertilizer, lime (dolomite), topsoil material, and compost, with proportion $49 \%, 1 \%, 10 \%, 20 \%$, $20 \%$ of media weight respectively. The results showed that three years after planting, ameliorant treatment plots showed growth percentage of E. urophylla, E. cyclocarpum, and S. saman as $96.1 \%, 73.4 \%$, and $52.4 \%$ respectively, while in the control plots were $94.1 \%, 93.8 \%$, and $35.0 \%$ respectively. The ameliorant treatment plots as compared to control plots, showed a significantly different effect on the growth parameters, both height and diameter for S. saman and E. cyclocarpum, while for E. urophylla, although the ameliorant treatment showed better growth parameters, but the differences were not significant.
\end{abstract}

Keywords: Soil properties, land rehabilitation, post-mining closure

\section{INTRODUCTION}

Tin with the Latin's name Stannum (Sn) was firstly mined around 5,000 years ago as a material to make bronze. Nowadays, the important use of tin is applied mainly as solder in electronics and industries, tinplate, and chemical applications (ITRI 2012; Pearce and Wallace 2015; Yang et al. 2018). Indonesia is the world's secondlargest tin producer after China, with the production reaching one-third of world tin production. In Indonesia, tin is one of the valuable mining resources that significantly support national gross domestic product (Rosyida et al. 2017). The richest tin deposits in the world are spread over South China, Burma, Thailand, Malaysia, and Indonesia. In Indonesia, the deposits are mainly located on the islands of Bangka, Belitung, Singkep, and Bintan (Salim and Munadi 2016) with Bangka and Belitung as the most productive island (Rosyida and Sasaoka 2018).

Tin is produced from the processing of mineral cassiterite (tin oxide) that occurs in deep hard rock or in shallow depth alluvial deposits (ITRI 2012). The surface mining system commonly destroys the land and decreases soil properties, consequently, this system declines ecological functions of the mining area (Omotehinse and Ako 2019). These phenomena occur in almost all mining locations in Indonesia, including tin mining in Bangka Island. Mostly tin exploitations in Bangka Island apply surface alluvial mining or open-pit mining techniques, result in various damage landscapes, the structure of rocks and soil layers. Although tin mining has positive impact to the economy by increasing the community income (Nurtjahya et al. 2017), but the mining causes demolition of landscapes, mixing of soil materials and overburden, water and wind erosions, sedimentation in rivers, decreasing water quality due to increased salinity and acidity in rivers (Djakamihardja and Noviardi 2009), and heavy metal contamination in the soil, sediment, and water resources (Puttiwongrak et al. 2019). In the field mostly found that the overburden spread over a large area, with relatively low fertility as compared to the original soil. Therefore, if post-mining closure of the tin-mined lands does not manage properly, it will cause negative effects both on-site and off-site of the mining area (Pratiwi et al. 2012; Narendra and Pratiwi 2014).

Moreover, the tin-mined land needs to be rehabilitated using adaptive tree species and supported by the application of soil ameliorant to improve the soil properties of overburden. In terms of soil properties, some studies emphasized the importance of soil physical and chemical properties in affecting plant growth and increase soil microbial activities (Manning et al. 2015). Soil ameliorant as an agent of soil physical and chemical properties can be applied in the form of compost as an organic matter source, and lime (dolomite) to increase soil $\mathrm{pH}$. Organic matter 
from the compost potentially increases soil water content, soil aggregate stability, and cation exchange capacity (CEC). It provides nutrient elements for the plant, and the carbon (C) for soil microorganism life (Estuningsih et al. 2015).

The adaptive species with good growth performance should be considerately used, not only really on native tree species because although the native trees have the adaptability to the tin-mined land if they have a slow growth rate is not necessarily to be used (Foroughbakhch et al. 2006). To do so, in the open-pit mining practices, the weathered materials that known as soil body's layers which are located on the overburden layers must be returned back on top of land to be comparable arrangement to their original condition.

According to the background above, this study aims to obtain data and information for setting up some techniques to improve the soil properties of post-tin-mined closure by applying the addition of ameliorant materials for supporting land rehabilitation of post tin mining closure in Bangka Island using some adaptive tree species. It is expected that these data, information, and techniques could be used by the government, mining companies or local communities in an effort to improve the productivity of post-tin-mined closure land.

\section{MATERIALS AND METHODS}

\section{Study area}

The study was conducted in the post-tin-mined closure land area in Central Bangka District, Bangka Belitung Islands Province, Indonesia (Figure 1). This area has a tropical climate with A rainfall type (according to the Oldeman climate classification system). Based on data from the Meteorological Station of Pangkal Pinang, the average rainfall in 2017 was $2643 \mathrm{~mm}$ with an average air temperature $27.0^{\circ} \mathrm{C}$. Average air humidity varies from 51 to $98 \%$ (BPS 2018). The soil type is dominated by the Yellowish Brown Podzolic (SRI 1966). In general, the tinmined in the research area has a flat to a wavy topography and the elevation is about $0-50 \mathrm{~m}$ above sea level.

\section{Procedures \\ Materials}

The research materials include plant seedlings and ameliorant. The plant seedlings comprise of Samanea saman (trembesi), Enterolobium cyclocarpum (sengon buto), and Eucalyptus urophylla (ampupu); whereas the ameliorants are a mixture of overburden, nitrogen $(\mathrm{N})$ phosphorus $(\mathrm{P})$ potassium $(\mathrm{K})$ fertilizer, lime (dolomite), topsoil, and compost. The tools used in the field were hoes, shovels, scales, and measuring instruments for plant height and diameter.

\section{Research design}

The research begins by determining the location in about 1 ha overburden area with relatively homogenous conditions. Planting holes with a size of $50 \times 50 \times 50 \mathrm{~cm}^{3}$ are made with a distance of $3 \times 3$ meters between the holes. The research applied the first treatment as control plots (without any treatment), and the second treatment was an adding mixture of overburden materials, NPK fertilizer, lime (dolomite), topsoil material, and compost, with proportion $49 \%, 1 \%, 10 \%, 20 \%, 20 \%$ of media weight respectively. The media that has been put into the planting hole was then allowed to stand for about one week to let stable conditions. Afterward, the plants are planted into the holes.

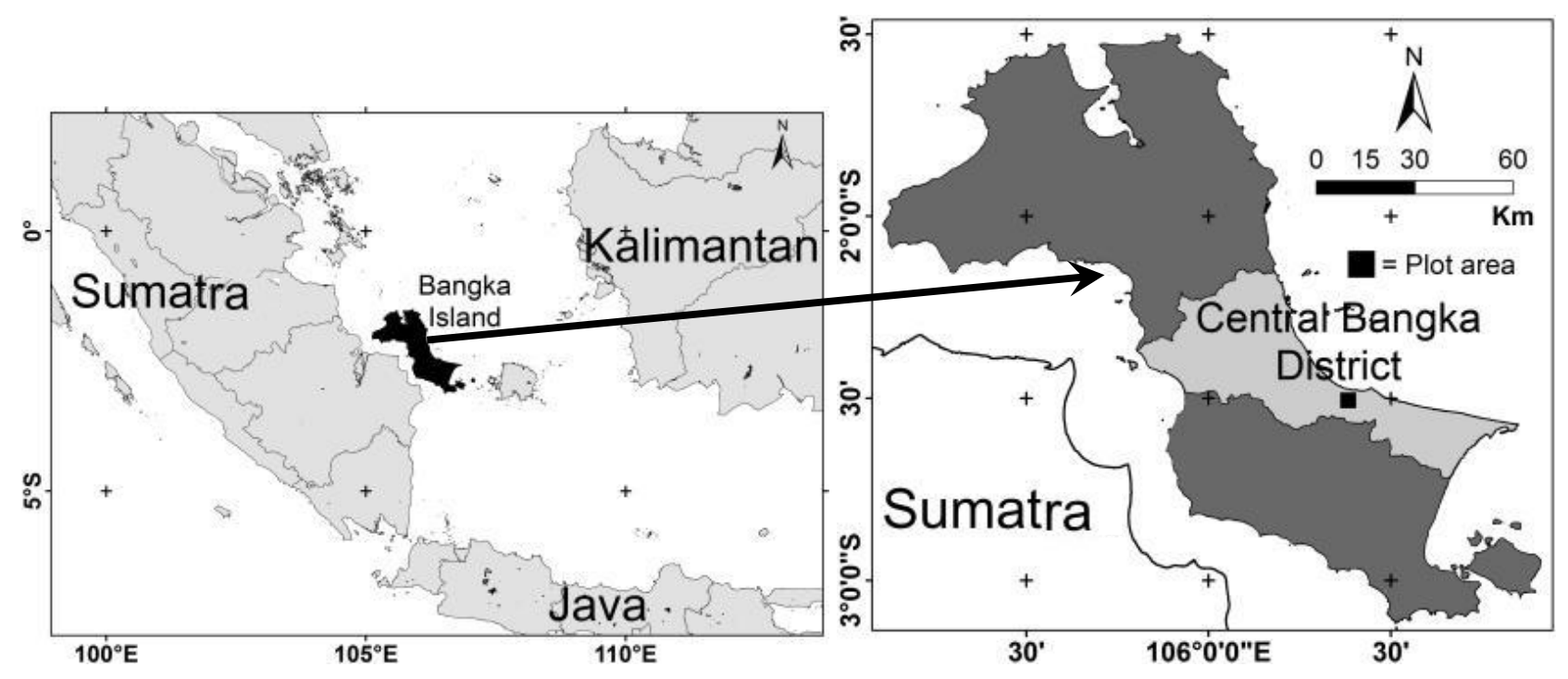

Figure 1. Map of the study area in Bangka Island, Indonesia 


\section{Data collection and analysis}

Observation and measurements of the plants include survival rate, stem height, and stem diameter. Plant's survival rates were analyzed three years after planting. Dimension measurements were carried out every half a year up to three years after planting. Stem heights were measured using a measuring pole from above the soil surface to the top of the plant, while the stem diameter was measured using a diameter tape at a base reference point located $5 \mathrm{~cm}$ above the soil surface (Kindermann et al. 2018; Lahti et al. 2005). Statistical analysis was conducted with mathematical models to find out the effects of treatment on trial plants in the field. A student's t-test was run to assess differences of stem height and diameter as the effect of treatments and the control (Walpole et al. 2012).

\section{RESULTS AND DISCUSSION}

\section{Physical and Chemical Properties}

Based on the results of previous studies (Pratiwi et al. 2012), the physical and chemicals properties of compost and topsoil are presented in Table 1.

The results of the materials analyses show that compost has alkaline $\mathrm{pH}$, high organic matter and low $\mathrm{P}$ content. While the overburden mixture has acidic $\mathrm{pH}$, high organic matter, low $\mathrm{P}$ and $\mathrm{K}$ contents, low Base Saturation (BS) and CEC and clay texture. Topsoil has acidic $\mathrm{pH}$, moderate organic matter, low $\mathrm{P}$, medium $\mathrm{K}$ content, low BS, medium CEC, and sandy loam texture. Overall the best microelements are present in compost, while the mixture of overburden and topsoil is less fertile.

Those soil properties indicate that the overburden has low fertility and high acidity therefore it should be improved. Additional use of ameliorant materials, such as compost, fertilizer, lime, and topsoil, is expected to allow neutralization of undesirable soil characteristics and increase the fertility in overburden area (Zenero et al. 2016).

\section{Plant survival percentage}

The plant's survival until the three years after planting presented in Table 2 shows that species with the highest survival percentage occurs in both the control and treatment plots are E. urophylla followed by $E$. cyclocarpum. The survival of E. urophylla and S. saman is better in the treated plot than in control. It means that these two species adapted in the more fertile land than the $E$. cyclocarpum, or it can be said that E. cyclocarpum is more adaptive in wider range of soil fertility than the other two species.

Eucalyptus urophylla is a fast-growing tree species widely cultivated by farmers and the timber industry. Its commercial varieties are superior to fast-growing local species because they are more efficient at capturing and using available water, light, and nutrients (Amazonas et al. 2018). In the plantation environment, the canopy able to cover the land in $2-3$ years after planting. It also has pests and disease resistance, fast growth, and adaptive to a wide range of soil and climate (Attia et al. 2019). This species shows the ability to survive in dry areas during planted in reforestation programs and resulting in the distribution in the almost whole area of Flores Island (Susila and Darwo 2015).

Enterolobium cyclocarpum is a legume tree species that is often planted for the purpose of soil conservation. This species has good adaptability to various soil conditions, including acid soils where other legumes species such as Leucaena and Gliricidia cannot grow well (Ezenwa and Sotolu 2000; Batista et al. 2018). In addition to the purpose of soil conservation, this species is also preferred as a component of agroforestry plants because of its rapid shoot and root growth characteristics, especially in the early months of growth so as to be able to provide biomass more quickly.

Table 1. Physical and chemical properties of materials (Pratiwi et al. 2012)

\begin{tabular}{|c|c|c|c|}
\hline Parameters & Compost & Topsoil & $\begin{array}{l}\text { Over- } \\
\text { burden }\end{array}$ \\
\hline $\mathrm{pH} \mathrm{H} \mathrm{H}_{2} \mathrm{O}$ & 7.9 & 5.7 & 3,5 \\
\hline $\mathrm{C}_{\text {org }}(\%)$ & 38.27 & 2.41 & 13,5 \\
\hline $\mathrm{N}_{\text {total }}(\%)$ & 1.68 & 0.16 & 0,86 \\
\hline $\mathrm{C} / \mathrm{N}$ ratio & 22.8 & 15.1 & 15,7 \\
\hline 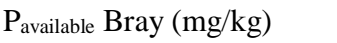 & - & 12.3 & 9,6 \\
\hline $\mathrm{P}_{2} \mathrm{O}_{5} \mathrm{HCl} 25 \%(\mathrm{mg} / \mathrm{kg})$ & 1.69 & 32.4 & 29,9 \\
\hline $\mathrm{K}_{2} \mathrm{O} \mathrm{HCl} 25 \%(\mathrm{mg} / \mathrm{kg})$ & 1.58 & 2.16 & 1,72 \\
\hline \multicolumn{4}{|l|}{ Exchangeable Cation $(\mathrm{cmol} / \mathrm{kg})$} \\
\hline $\mathrm{Ca}$ & & 2.79 & 0.63 \\
\hline $\mathrm{Mg}$ & & 2.63 & 1.42 \\
\hline $\mathrm{K}$ & & 0.81 & 0.73 \\
\hline $\mathrm{Na}$ & & 0.42 & 0.56 \\
\hline Total & & 6.65 & 3.34 \\
\hline $\mathrm{CEC}(\mathrm{cmol} / \mathrm{kg})$ & & 18.21 & 16.35 \\
\hline Base Saturation (BS) (\%) & & 36.5 & 20.4 \\
\hline \multicolumn{4}{|l|}{ Acidity $(\mathrm{cmol} / \mathrm{kg})$ : } \\
\hline $\mathrm{Al}^{+3}$ & & 0.24 & 1.89 \\
\hline $\mathrm{H}^{+}$ & & 0.43 & 6.35 \\
\hline \multicolumn{4}{|l|}{ Micro elements $(0.05 \mathrm{~N}$} \\
\hline \multicolumn{4}{|l|}{$\mathrm{HCl})(\mathrm{mg} / \mathrm{kg}):$} \\
\hline $\mathrm{Cu}$ & 61.7 & 0.8 & 2.3 \\
\hline $\mathrm{Zn}$ & 103.8 & 6.8 & 62.7 \\
\hline $\mathrm{Mn}$ & 61.3 & 81.4 & 28.9 \\
\hline $\mathrm{Fe}$ & 38.9 & 39.8 & 78.1 \\
\hline \multicolumn{4}{|l|}{ Texture: } \\
\hline Sandy & & 61.5 & 6.7 \\
\hline Loam & & 13.8 & 30.9 \\
\hline \multirow[t]{2}{*}{ Clay } & & 24.7 & 62.4 \\
\hline & & (Sandy loam) & (Clay) \\
\hline
\end{tabular}

Table 2. Survival percentage (\%) at three years after planting

\begin{tabular}{llcc}
\hline \multirow{2}{*}{ Species } & \multirow{2}{*}{ Local name } & \multicolumn{2}{c}{ Survival rate (\%) } \\
\cline { 3 - 4 } & & Control & Treatment \\
\hline Eucalyptus urophylla & Ampupu & 94.1 & 96.1 \\
Samanea saman & Trembesi & 35.0 & 52.4 \\
Enterolobium cyclocarpum & Sengon buto & 93.8 & 73.4 \\
\hline
\end{tabular}


Likewise in the case of nodule formation, $E$. cyclocarpum is faster in forming nodules than Leucaena species (Ezenwa and Sotolu 2000). In Africa, the use of this species in alley systems provide a role in increasing soil fertility, improving soil structure, preventing erosion, and producing a variety of products such as wood, animal feed, and fuelwood (Pacheco et al. 2012).

Samanea saman is categorized as a fast-growing tree and has high adaptability to various soil types, $\mathrm{pH}$, and texture. In the barren land or planting with a wide space, the tree's canopy horizontally can grow higher than the tree's height. A research conducted in the coal post-mining rehabilitation showed that $S$. saman has the highest survival rate than two other species, Casia siamea and Falcataria moluccana (Budiana et al. 2017). This growth characteristic coupled with abundant seed production makes this species should be considered carefully when utilized in the rehabilitation program especially for the location near conservation areas (Nuroniah and Kosasih 2010).

\section{Height and diameter growth of plants}

The height and diameter growth of plants in the three years after planting is presented in Table 3 and Figure 2. The results showed that in the third year the ameliorant treatment improves significantly to the growth of $S$. saman and E. cyclocarpum as indicated by height and diameter parameters. Whereas for the E. urophylla although ameliorant treatment produced better growth, it is not significantly different as compared to the control plot. This E. urophylla's growth is similar to the measurement result in the location of Pujon, East Java and Subanjeriji, South Sumatera. In Pujon, the diameter and height growth was recorded $1.8 \mathrm{~cm} /$ year and $1.4 \mathrm{~m} /$ year respectively, while in Subanjeriji the growth was $2.0 \mathrm{~cm} /$ year and $1.8 \mathrm{~m} /$ year for the diameter and height growth respectively. Lower growth was reported from E. urophylla stand in Flores, East Nusa Tenggara that resulting in the diameter growth $1.2 \mathrm{~cm} /$ year and $0.8 \mathrm{~m} /$ year for the heigh growth (Susila and Darwo 2015; Sirait 2000).

\section{Discussion}

In the research location, tin mining was carried out by the surface mining system, resulting in topographic changes and soil surface damages including loss of flora and fauna and their living environment. Adewole and Adesina (2010) said that tin mining activities cause loss of natural flora and fauna biodiversity, cessation of soil microbiology activities, and decreased properties of soil productivity. Furthermore, Sujitno (2007) stated that mining activities will result in changes in the physical and chemical properties of the soil.

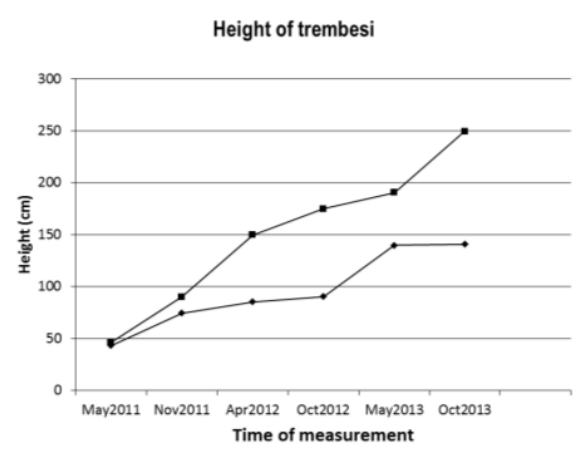

Diameter of trembesi

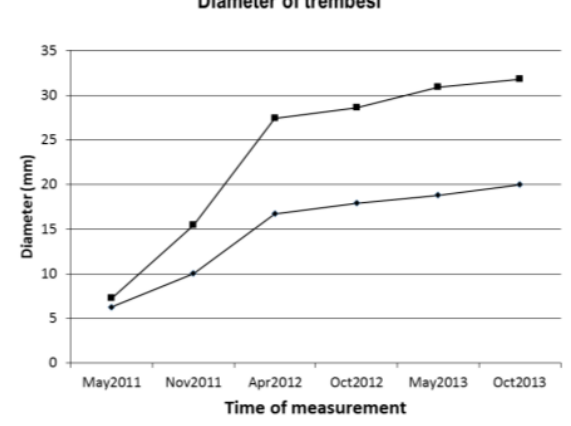

$\mathbf{A}$

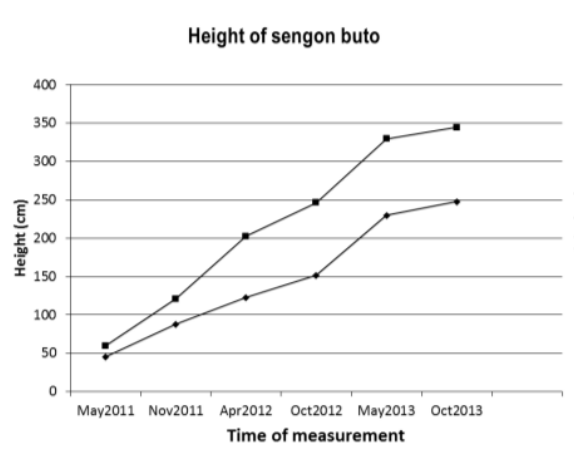

Diameter of sengon buto

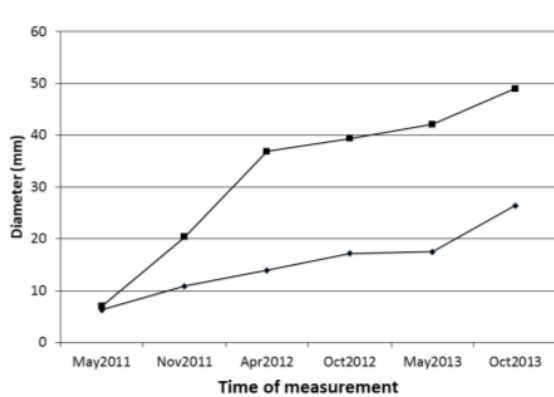

B
Height of ampupu
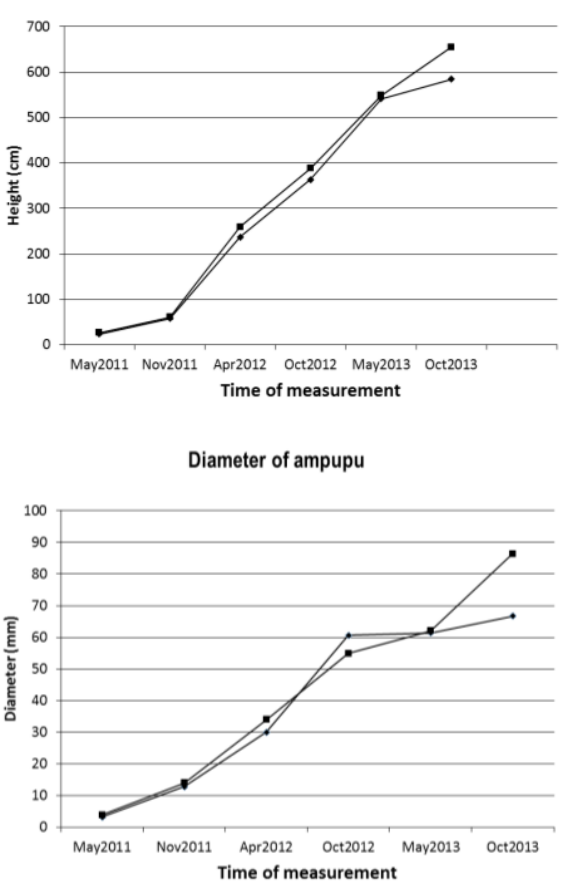

C

Figure 2. Height and diameter growth of: A. Samanea saman, B. Enterolobium cyclocarpum, C. Eucalyptus urophylla. Note: $\rightarrow-$ : Control; $\rightarrow-$ : Treatment 
Table 3. Height and diameter of plants at three years after planting

\begin{tabular}{|c|c|c|c|c|c|c|}
\hline \multirow[t]{2}{*}{ Parameters } & \multicolumn{2}{|c|}{$\begin{array}{c}\text { Eucalyptus urophylla } \\
\text { (ampupu) }\end{array}$} & \multicolumn{2}{|c|}{$\begin{array}{c}\text { Enterolobium cyclocarpum } \\
\text { (sengon buto) }\end{array}$} & \multicolumn{2}{|c|}{$\begin{array}{c}\text { Samanea saman } \\
\text { (trembesi) }\end{array}$} \\
\hline & Control & Treatment & Control & Treatment & Control & Treatment \\
\hline Height $(\mathrm{cm})$ & 584.0 & 654.5 & 247.7 & $344.4 * *$ & 140.7 & $249.5 * *$ \\
\hline Diameter $(\mathrm{mm})$ & 66.7 & 86.3 & 26.4 & $49.0^{* *}$ & 20.0 & $31.8 * *$ \\
\hline
\end{tabular}

Note: $* *$ : Significantly different at $99 \%$

Mining activities in the study site remain lands with a mixture of overburden with other materials. The problems are that the properties of the overburden mixture have a low $\mathrm{pH}$ (4-5), low microbial and nutrient content and the presence of dissolved heavy minerals. The land of postmining closure should be useable and productive to make a better and productive environment of tin mined land. Therefore the post-tin-mining closure land needs to be improved and managed.

In general, the soil fertility level of post tin mining closure land, especially in tailings, is very low due to the loss of topsoil, nutrient leaching and changes in physical, chemical and biological properties (Donova and Casey 1998), resulting in soil and land properties degradation. Basic characteristics of post-tin-mining closure land are generally containing quartzitic sand in a quite high percentage so that fertility level of this soil is very low due to low clay and organic matter content and consequently the soil buffer capacity is low, then nutrient elements easily leached out. Clay and organic matters have functioned as temporal holders of fertilizer elements, known as buffer function because they have negative charges. Besides that, both of these materials can improve the structure and moisture of the soil. The use of organic fertilizer physically enhance soil permeability and aggregate stability and decrease soil compaction (Oliveira et al. 2014). Moreover, specifically, soil organic matter can improve soil biological properties and increase soil $\mathrm{pH}$. Besides the addition of clay and organic matter, improvement in soil properties needs to be done by adding lime to improve soil reactions by increasing soil $\mathrm{pH}$ so that the soil $\mathrm{pH}$ increase and soil reaction improved. With this treatment, it is expected that the soil properties of post-mining closure are better, then accelerates and increases the success of land rehabilitation.

The results showed that overburden had a $\mathrm{pH}$ of 3.5 because overburden contained sulfidic materials such as pyrite, calco-pyrite, marcasite, etc. containing iron and sulfide under reduced conditions. When the overburden dried, the environment is more in oxidized condition, then the sulfidic materials are oxidized and dissolved to become $\mathrm{Fe}^{2+}$ and $\mathrm{S}^{2-}$. Furthermore, these ions are hydrolyzed produce large quantities of $\mathrm{H}^{+}$ions. Therefore overburden has a low $\mathrm{pH}$. The topsoil has a $\mathrm{pH}$ around neutral, because there is no sulfidic material, while compost has a $\mathrm{pH}$ of 7.9, this means the compost has matured already. This compost material is good to be used as fertilizer. The addition of fertilizer, compost, and lime can improve the $\mathrm{pH}$ of the soil becomes neutral.
Overburden has high $\mathrm{C}$ content, compared to the topsoil because overburden in the research site contains layers with a lot of organic material result of deposition. $\mathrm{N}$ content in the overburden is also higher than in topsoil. However, the overall compost has the highest content of $\mathrm{C}$ and $\mathrm{N}$ compared to the topsoil and overburden. Therefore mixing between material with rich in $\mathrm{C}$ and $\mathrm{N}$ will produce fairly good medium. The $\mathrm{C} / \mathrm{N}$ ratio of all ameliorant materials is low. These show that the organic material from all the materials has reached equilibrium in their decomposition.

According to Table 1, all materials including compost, topsoil, and overburden have low $\mathrm{P}$ content. $\mathrm{P}$ content in soil comes from organic matter, fertilizers and minerals in the soil. $\mathrm{P}$ is most easily absorbed by plants at a $\mathrm{pH}$ of about 6-7. If soil lacks $\mathrm{P}$, cell propagation in plants is inhibited and the plant is stunting (Hardjowigeno 2003). Therefore, to improve this planting media, the fertilizers need to be added.

$\mathrm{K}$ is the third essential plant nutrient after $\mathrm{N}$ and $\mathrm{P}$ which is absorbed by plants as $\mathrm{K}^{+}$ions. $\mathrm{K}^{+}$ions dissolved from weathering rocks and minerals containing $\mathrm{K}$. The $\mathrm{K}$ also available through the decomposition of plant material and microorganisms, where the $\mathrm{K}$ will dissolve and return to the soil. Furthermore, most soluble soil $\mathrm{K}$ will be washed out or eroded and this loss process will be accelerated by re-uptake of plants and microorganisms (Marpaung, 2011). Some soil types contain abundant $\mathrm{K}$ that comes from the feldspar group of minerals that release during rock and mineral weathering. Data on soil analysis show that $\mathrm{K}$ in topsoil and overburden are high.

The result of analyses shows that the Calcium $(\mathrm{Ca})$ of the topsoil was low (Pratiwi et al. 2012) and that of overburden was very low. According to Leiwakabessy (1988), Ca is essential minerals like Magnesium (Mg) and Sulfur (S). $\mathrm{Ca}^{2+}$ in the solution can be depleted because it is absorbed by plants and microorganisms, bound by a soil adsorption complex, recrystallized as secondary minerals and leached out. The functions of $\mathrm{Ca}^{2+}$ in plant metabolism are to activate the formation of root, especially fine roots, formation of seeds, strengthening the stems, increasing the success of pollination, to help breakdown cells, to increase the activity of several enzymes (Pallardy 2008; Widodo and Sudradjat 2016), while $\mathrm{Mg}$ is a chlorophyll forming element, therefore $\mathrm{Mg}$ deficiency results in distinctive leaves color changes (Hanafiah 2005). The results of soil analysis showed that the $\mathrm{Mg}$ content of topsoil was high, while in the overburden was medium. 
The overburden contains very high $\mathrm{Fe}$ due to the oxidation of sulfidic minerals such as pyrite $\left(\mathrm{FeS}_{2}\right)$. Oxidation of sulfidic minerals produces $\mathrm{Fe}^{2+}$ and $\mathrm{S}^{2-}$ Furthermore hydrolyzes of these ions produces acidic condition with a $\mathrm{pH}$ around 3 , and the solubility of metal elements such as aluminum $(\mathrm{Al})$, iron $(\mathrm{Fe})$, Mangan $(\mathrm{Mn})$, etc. increase significantly that causes toxic to plants. This phenomenon is referred to as acid mine drained.

The soil texture indicates the roughness or smoothness of soil materials of the studied area. The texture is a relative comparison of sand, dust, and clay particle fractions that smaller than gravel. Soil texture is related to permeability, water holding capacity, aeration, CEC, and soil fertility. The results of soil analysis showed that the texture of the topsoil is sandy loam, while of the overburden is clay. Soil with clay texture has low permeability, while water holding capacity and CEC is relatively high compared to sand-textured soil.

Analysis of plant survival shows that in general plants that grown on the post-tin-mining closure land with ameliorant treatment have better survival and growth than without the treatment. This means that the addition of ameliorant materials improves the soil properties and increasing the carrying capacity of the post-tin-mining closure land for supporting land rehabilitation success. Although E. urophylla has the best survival, growth, and potentially faster in covering the post tin mining closure land than two other species, the use it in rehabilitation program should not in a monoculture species. It is better to mix with various fast-growing native tree species to get better conditions in supporting ecological processes. E. urophylla mixed plantation with only $50 \%$ of E. urophylla proportion, potentially grows $75 \%$ higher than in the monoculture. Monoculture plantations tend to have higher surface runoff, soil erosion and nutrient losses than the mixed species, therefore the mixed-species offer a multipurpose plantation especially in the context of postmining closure land rehabilitation (Chu et al. 2019). To prevent soil nutrient deficiency and site degradation, the mixing with $\mathrm{N}$-fixing species are recommended.

\section{ACKNOWLEDGEMENTS}

The authors would like to acknowledge the Forest Research and Development Center, Ministry of Environment and Forestry Republic of Indonesia for the funding of this research. We gratefully acknowledge the support of PT. Koba Tin during fieldwork.

\section{REFERENCES}

Adewole MB, Adesina MA. 2011. Impact of marble mining on soil properties in part of Guinea Savanna zone of Southernwestern Nigeria. Ethiop J Environ Stud Manag 4: 1-8.

Amazonas NT, Forrester DI, Silva CC, Almeida DRA, Rodrigues RR, Brancalion PHS. 2018. High diversity mixed plantations of Eucalyptus and native trees: An interface between production and restoration for the tropics. For Ecol Manag 417: 247-256. DOI 10.1016/j.foreco.2018.03.015.
Attia A, Nouvellon Y, Cuadra S, Cabral O, Laclau JP, Guillemot J, Campoe O, Stape J, Galdos M, Lamparelli R, Maire G .2019. Modeling carbon and water balance of Eucalyptus plantations at regional scale: Effect of climate, soil and genotypes. For Ecol Manag 449. DOI: $10.1016 /$ j.foreco.2019.117460.

Batista AQ, Coelho CF, Miranda IPA, Barbosa EM. 2018. The Effect of Different Substrates on the Growth of Enterolobium contortisiliquum. J Agric Sci 10 (3): 197-203. DOI: 10.5539/jas.v10n3p197.

BPS [Badan Pusat Statistik]. 2018. Bangka Tengah Regency in figures. BPS-Statistics of Bangka Tengah Regency, Pangkal Pinang.

Budiana IGE, Jumani, Biantary MP. 2017. Evaluation of revegetation of the former coal mining area at PT Kitadin, site Embalut, Kutai Kartanegara Regency, East Kalimantan. Agrifor 16 (2): 195-208.

Chu S, Ouyang J, Liaoa D, Zhoub Y, Liu S, Shenb D, Wei X, Zeng S. 2019. Effects of enriched planting of native tree species on surface water flow, sediment, and nutrient losses in a Eucalyptus plantation forest in southern China. Sci Total Environ 675: 224-234. DOI: 10.1016/j.scitotenv.2019.04.214.

Djakamihardja AS, Noviardi R. 2009. Post-tin-mined land rehabilitation in West Bangka: Alternative utilization of organic waste. Research result proceeding of Geotechnology Research Center, Bandung, 10 December 2008. [Indonesian]

Donova G, Casey C. 1998. Soil fertility management in Sub Sahara Africa. Phosphorous and Nitrogen based manure and compost application. Agron J 94: 128-135.

Estuningsih SP, Tanzerina N, Oktarisma D. 2015. Effect of ameliorant in phytoremediation of coal post-mining in PT Bukit Asam, Tanjung Enim, South Sumatera. National seminar proceeding of sub-optimal land. Sriwijaya University, Palembang, 8-9 October 2015

Ezenwa I and Sotolu OA. 2000. Comparison of early root and shoot growth and nodulation of Enterolobium, Leucaena, Gliricidia. Intl $\begin{array}{llllll}\text { Tree Crops } & \text { J. } 10 & \text { (3): } 229-235 . & \text { DOI: }\end{array}$ 10.1080/01435698.2000.9753009.

Foroughbakhch R, Alvarado-Vazquez MA, Hernandez-Pinero JL, RochaEstrada A, Guzman-Lucio MA, Treviño-Garza EJ. 2006. Establishment, growth and biomass production of 10 tree woody species introduced for reforestation and ecological restoration in northeastern Mexico. For Ecol Manag 235: 194-201.

Hanafiah KA. 2005. Fundamental of soil science. Raja Grafindo Persada, Jakarta. [Indonesian]

Hardjowigeno S. 2003. Soil science. Akademika Pressindo, Jakarta. [Indonesian]

ITRI [International Tin Research Institute]. 2012. Tin for tomorrow: contributing to global sustainable development. ITRI Ltd, St Albans.

Kindermann GE, Kristöfel F, Neumann M, Rössler G, Ledermann T, Schueler S. 2018. 109 years of forest growth measurements from individual Norway spruce trees. Sci Data 5: 180077. DOI: 10.1038/sdata.2018.77(2018).

Lahti M, Aphalo PJ, Finer L, Ryyppo A, Lehto T, Mannerkoski H. 2005. Effect of soil temperature on shoot and root growth and nutrient uptake of 5-year-old Norway spruce seedlings. Tree Phys 25: 115122. DOI: $10.1093 /$ treephys/25.1.115.

Leiwakabessy FM. 1988. Soil fertility. Department of Soil Science, Bogor Agricultural University, Bogor. [Indonesian]

Manning P, Vries FT, Tallowin JRB, Smith R, Mortimer SR, Pilgrim ES, Harrison KA, at al. 2015. Simple measures of climate, soil properties and plant traits predict national-scale grassland soil carbon stocks. J Apl Ecol 52: 1188-1196. DOI: 10.1111/1365-2664.12478.

Narendra BH, Pratiwi. 2014. Cover crops growth on tin mined overburden in Bangka Island. Indon For Rehab J 2 (1): 15-24.

Nuroniah HS and Kosasih AS. 2010. Knowing trembesi (Samanea saman (Jacquin). Merrill) as a shading tree. Jurnal Mitra Hutan Tanaman 5 (1): 1-5. [Indonesian]

Nurtjahya E, Franklin J, Umroh, Agustina F. 2017. The Impact of tin mining in Bangka Belitung and its reclamation studies. MATEC Web of Conferences 101 (04010): 1-6. DOI: 10.1051/matecconf/ 201710104010

Oliveira LB, Accioly AMA, Santos CLR, Flores RA, Barbosa FS. 2014. Características químicas do solo e produção de biomassa de alface adubada com compostos orgânicos. Rev Bras Eng Agríc Ambient 18 (2): 157-164. DOI: 10.1590/S1415-43662014000200005

Omotehinse AO, Ako BD. 2019. The environmental implications of the exploration and exploitation of solid minerals in Nigeria with a special focus on Tin in Jos and Coal in Enugu. J Sus Min 18: 18-24.

Pacheco MMM, Río RED, García AF, Muñoz REM, Echeverría OAR, González DR. 2012. Enterolobium cyclocarpum (Jacq.) Griseb.: The 
biotechnological profile of a tropical tree. Bol Latinoam Caribe Plant Med Aromat 11 (5): 385 -399.

Pallardy SG. 2008. Physiology of woody plants. 3rd ed. Academic Press, Burlington.

Pearce J, Wallace T. 2015. Tin Chemicals Roadmap 2015. ITRI Ltd, St Albans.

Pratiwi, Santosa E, Turjaman M. 2012. Determination of ameliorant compounds dosage for soil of quartzitic sandy tailing as forest seedlings media. Jurnal Penelitian Hutan dan Konservasi Alam 9 (2): 163-174. [Indonesian]

Puttiwongrak A, Suteerasak T, Mai PK, Hashimoto K, Gonzalez JC, Rattanakom R, Prueksakorn K. 2019. Application of multi monitoring methods to investigate the contamination levels and dispersion of $\mathrm{Pb}$ and $\mathrm{Zn}$ from tin mining in coastal sediments at Saphan Hin, Phuket, Thailand. J Clean Prod 218: 108-117. DOI: 10.1016/j.jclepro.2019.01.254

Rosyida I, Khan W, Sasaoka M. 2017. Marginalization of a coastal resource-dependent community: A study on tin mining in Indonesia. Extractive Industr Soc 5 (1): 165-176

Rosyida I, Sasaoka M. 2018. Local political dynamics of coastal and marine resource governance: A case study of tin-mining at a coastal community in Indonesia. Environ Dev 26: 12-22. DOI: 10.1016/j.envdev.2018.03.003
Salim Z, Munadi E. 2016. Tin commodity information. Trade Assessment and Development Agency, Jakarta.

Sirait IR. 2000. Model establishment of diameter and height growth of Eucalyptus urophylla S.T. Blake. [Thesis]. Bogor Agricultural University, Bogor. [Indonesian]

SRI [Soil Research Institute]. 1966. Soil map of Bangka and Belitung. LPT, Bogor. [Indonesian]

Sujitno S. 2007. Tin history in Bangka Island. PT Tambang Timah TBK, Pangkal Pinang. [Indonesian]

Susila IWW, Darwo. 2015. The increment and volume estimation of eucalypt stand at Wololobo forest area, Bajawa, Flores. Jurnal Penelitian Hutan Tanaman. 12 (2): 105-113. [Indonesian]

Walpole RE, Myers RH, Myers SL, Ye K. 2012. Probability and statistics for engineers and scientists. Prentice-Hall, Boston.

Widodo HH, Sudradjat. 2016. Role of calcium fertilizer on young plant of oil palm. Bul Agrohorti 4 (3): 276-281.

Yang C, Tan Q, Zeng X, Zhang Y, Wang Z, Li J. 2018. Measuring the sustainability of tin in China. Sci Total Environ 635: 1351-1359. doi: 10.1016/j.scitotenv.2018.04.073.

Zenero MDO, Silva LFS, Castilho SCP, Vidal A, Grimaldi M, Cooper M. 2016. Characterization and classification of soils under forest and pasture in an agroextractivist project in Eastern Amazonia. Revista Brasileira de Ciência do Solo 40: 1-17. DOI: 10.1590/18069657rbcs20160165. 